Research Article

\title{
Ondansetron versus palonosetron: a comparative study on efficacy and safety in prevention of postoperative nausea and vomiting
}

\author{
Bhanu Prakash G.*, Umamaheswara Rao K., Subash K. R., Vijaya Chandra Reddy K., \\ Jyothi Prasad K., Vasundara Devi B.
}

\begin{abstract}
SVIMS, Sri Padmavathi
Medical College for Women, SVIMS University, Tirupati, Andhra Pradesh, India
\end{abstract}

Received: 02 June 2016 Accepted: 07 June 2016

*Correspondence to:

Dr. G. Bhanu Prakash, Email: drbhanuprakash11 @yahoo.com

Copyright: (C) the author(s), publisher and licensee Medip Academy. This is an openaccess article distributed under the terms of the Creative Commons Attribution NonCommercial License, which permits unrestricted noncommercial use, distribution, and reproduction in any medium, provided the original work is properly cited.

\begin{abstract}
Background: Postoperative nausea and vomiting (PONV) is a major complication in patients who undergo surgery under general anaesthesia. Various drug regimens and antiemetic interventions have been tried from timeto-time for prevention of PONV but with a variable success rate. This study compares the safety and efficacy of ondansetron and palonosetron in preventing PONV in such patients.

Methods: A prospective study was conducted in 60 ASA grades - I and II patients of either sex, aged between 20 to 50 years, scheduled for elective surgery under general anaesthesia, 30 of who received $4 \mathrm{mg}$ ondansetron and the remaining 30 received $0.05 \mathrm{mg}$ palonosetron intravenously 5 minutes before induction of anaesthesia. Postoperatively they were observed for 24 hours for complete response, any episodes of nausea and vomiting, their severity, need for rescue antiemetic and side effects. After the study, results were compiled and the data was analysed using Student's T test. P value $<0.05$ was considered significant.
\end{abstract}

Results: PONV was $40 \%$ in ondansetron group and $17 \%$ in palonosetron group ( $p>0.5$ ). Complete antiemetic response was $60 \%$ in ondansetron group and $83 \%$ in palonosetron group. There was no significant statistical difference between both the groups in causing headache $(p>0.5)$ and dizziness $(p>0.05)$.

Conclusions: Our study concludes that the antiemetic efficacy is comparable for both ondansetron and palonosetron in the given doses in preventing PONV and none is superior. Both the study drugs had almost the same adverse effect profile.

Keywords: Surgery, General anaesthesia, PONV, Ondansetron, Palonosetron

\section{INTRODUCTION}

PONV is defined as any nausea, retching or vomiting occurring during the first 24-48 hours after surgery in inpatients. Though often temporary, it is unpleasant, with reported incidences of $30 \%$ in all post-surgical patients and up to $80 \%$ in high-risk patients. ${ }^{1}$ In the recovery room $20 \%$ of patients suffer with nausea and $5 \%$ with vomiting while even thereafter, $50 \%$ suffer with nausea and $25 \%$ with vomiting. ${ }^{2}$

Wound dehiscence, dehydration, electrolyte imbalance and rarely aspiration pneumonitis are the PONV associated morbidities that can lead to prolonged hospital stay of the patient, thereby increasing the healthcare costs. ${ }^{1}$ The genesis of PONV is 'multifactorial', involving operative, anaesthetic and patient-specific risk factors. Several receptors like dopaminergic, cholinergic, histaminic and serotonergic are involved in the pathophysiology of vomiting. ${ }^{3}$ The treatment or prophylaxis of PONV involves antagonists of the above mentioned receptors. Among them, 5- $\mathrm{HT}_{3}$ antagonists like ondansetron, granisetron, dolasetron, tropisetron and palonosetron have gained importance. ${ }^{4}$ For the 24 hours recovery period after surgery, the percentages of emesisfree patients were $65.5 \%, 52 \%$ and $48 \%$ in the ondansetron, granisetron and tropisetron groups respectively when the study drugs were given as a short I.V. infusion 10 minutes before the induction of anesthesia. $^{5}$ 
A single $0.075 \mathrm{mg}$ I.V. dose of palonosetron significantly increased the complete response rate (no emetic episodes and no rescue medication) from 0 to 24 hours, decreased the severity of nausea and patients experienced significantly less interference in their postoperative function due to PONV. ${ }^{6}$ Differences in binding and effects on $5-\mathrm{HT}_{3}$ receptor function may be relevant to the unique beneficial actions of palonosetron. ${ }^{7}$ Palonosetron is a comparatively better drug to prevent the PONV in patients undergoing day care surgical procedures when compared to ondansetron as it has got a prolonged duration of action and favourable side-effect profile. ${ }^{8}$ Palonosetron is more effective than ondansetron for highrisk patients receiving fentanyl-based patient controlled analgesia after thyroidectomy, especially 2-24 hours after surgery. ${ }^{9}$ The current study is an effort to identify the efficacy and safety of $4 \mathrm{mg}$ ondansetron against $0.05 \mathrm{mg}$ palonosetron in the prophylaxis of PONV.

\section{METHODS}

We commenced an open label, prospective and comparative study after getting approval from the institutional ethics committee and obtaining written informed consent in local language from 60 patients fulfilling grade I and grade II of American society of anaesthesiologists (ASA) classification, of either sex in the age group of 20 to 50 years, who were scheduled for elective surgery under general anaesthesia at government general hospital, Kurnool, India from October 2011 to December 2011. The exclusion criteria were patients who were pregnant and lactating mothers, those with history of allergy to any of the two study drugs, history of motion sickness, history of substance abuse, anti-emetic or psychoactive medication within preceding 24 hours of surgery, gastrointestinal, liver or kidney disease, patients on cancer chemo radiation, those shifted to ICU and ventilated for postoperative care.

After screening the subjects based on laid inclusion/exclusion criteria, a total of 60 were enrolled in the study and divided equally into two groups, group $\mathrm{O}$ $(n=30)$ received single I.V. injection of ondansetron $4 \mathrm{mg}$ and group $\mathrm{P}(\mathrm{n}=30)$ received a bolus dose of palonosetron $0.05 \mathrm{mg} 5$ minutes prior to induction. A standardized anaesthetic regimen was followed in our study. All were premedicated with tab. Alprazolam $0.25 \mathrm{mg}$ and tab. ranitidine hydrochloride $150 \mathrm{mg}$ orally night before surgery and morning on the day of surgery. They were kept nil by mouth for 8 hours before surgery. General anaesthesia was induced with thiopentone sodium (5-7 $\mathrm{mg} / \mathrm{kg}$ ) I.V. and after appropriate face mask ventilation, endotracheal intubation was facilitated with I.V. vecuronium $0.1 \mathrm{mg} / \mathrm{kg}$. Intravenous fluids were given to the patients intraoperatively as needed. Propofol was consciously avoided in this study, as it has antiemetic property. ${ }^{10}$ After intubation, bilateral air entry was checked, tube fixed and then connected to mechanical ventilator support with an adequate tidal volume of 6-8 $\mathrm{ml} / \mathrm{kg}$ and respiratory rate 12 breaths/min. Anaesthesia was maintained with inhalational agents $\mathrm{N}_{2} \mathrm{O} 66 \%, \mathrm{O}_{2}$ $33 \%$, halothane $0.5-1 \%$. Vecuronium, $1 / 8^{\text {th }}$ of the loading dose, was given as maintenance dose for muscle relaxation. For intraoperative analgesia fentanyl 1-2 $\mu \mathrm{g} / \mathrm{kg} \mathrm{I.V}$. was given. At the end of surgery, as soon as the patients had attempts of spontaneous breathing, the residual neuromuscular block was reversed with neostigmine $(0.05 \mathrm{mg} / \mathrm{kg} \mathrm{I.V.)}$ and glycopyrrolate $(0.005$ $\mathrm{mg} / \mathrm{kg} \mathrm{I.V.).} \mathrm{The} \mathrm{patients} \mathrm{were} \mathrm{extubated} \mathrm{when} \mathrm{they} \mathrm{were}$ fully awake and gained adequate muscle power. The duration of surgery in all patients was noted. Tramadol $50 \mathrm{mg}$ BD I.M. was used in both the groups for postoperative analgesia. Patients were observed in the post anaesthetic care unit before transferred to the postoperative ward. The incidence and intensity of nausea, vomiting, and complete response were evaluated using visual analogue scale (VAS) for 24 hours. VAS score was recorded in both the groups at 0-2 hours (early) and 2-24 hours (delayed) postoperatively from the time of end of surgery. VAS score was measured by moving a pointer or finger along VAS which is divided into 10 equal parts and implicates no nausea/vomiting at one end 0 and severe nausea/vomiting at another end 10 .

VAS-score considered is as follows:

- 0 as no nausea and vomiting

- 1-4 as mild nausea/emetic effect

- 4-6 as moderate nausea/emetic effect

- 6-10 as severe nausea/emetic effect or unsatisfactory anti-emetic/anti-nausea effect

Vomiting was defined as the forceful expulsion of gastric contents from the mouth. Nausea was defined as the subjectively unpleasant sensation associated with awareness of the urge to vomit. Complete response was defined as no PONV and no need for any rescue antiemetic medication. Rescue antiemetic (ondansetron $4 \mathrm{mg}+$ dexamethasone $5 \mathrm{mg}$ (both I.V.)) was used if patient had vomiting. ${ }^{11}$ Side effects like headache, constipation, diarrhoea, dizziness, fatigue, abdominal pain, insomnia if any, in the 24 hours study period were recorded. ${ }^{12,13}$ Graphpad Instat 3 was used to statistically analyse the data employing unpaired Student's T test. A $\mathrm{p}$-value $<0.05$ was considered to be significant.

\section{RESULTS}

Both groups were comparable in terms of age, sex, weight, ASA physical status and duration of surgery (Table 1). Type of surgeries done was almost comparable in both the groups as shown in Figure 1. The overall incidence of PONV in early and delayed postoperative periods in the two groups was statistically insignificant (Table 2). No statistically significant differences were observed in the severity of PONV both in the early and delayed postoperative periods $(p>0.05)$ between the two groups as shown in Table 3. 
Only $60 \%$ in group $\mathrm{O}$ while $83 \%$ in group $\mathrm{P}$ showed complete response to the study drug $(\mathrm{p}>0.5)$, statistically insignificant (Table 4).

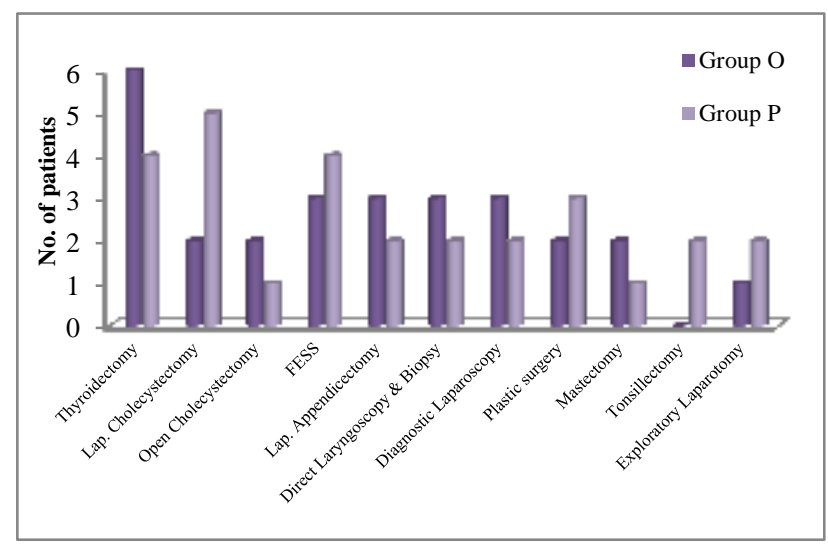

Figure 1: Types of surgeries done.

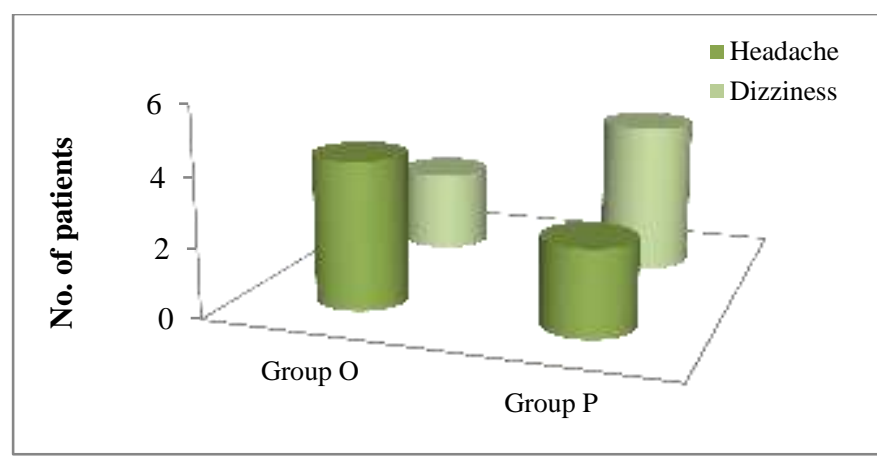

Figure 2: Safety profile of study drugs.

Need of rescue antiemetic was in 9 patients (30\%) in group $\mathrm{O}$ and in 5 patients $(17 \%)$ in group $\mathrm{P}(\mathrm{p}>0.5)$, statistically not significant (Table 4). The adverse effects were almost same and insignificant in both the groups (Figure 2).

Table 1: Demographic profile.

\begin{tabular}{|llll|}
\hline Variables & Group O $(\mathbf{n = 3 0})$ & Group P $(\mathbf{n = 3 0})$ & P-value \\
\hline Age $($ years) $($ mean \pm SD) & $34.53 \pm 9.52$ & $35.47 \pm 9.33$ & $0.70^{*}$ \\
\hline Sex $(\mathrm{M} / \mathrm{F})$ & $14 / 16$ & $17 / 13$ & - \\
\hline Weight $(\mathrm{kg})($ mean $\pm \mathrm{SD})$ & $48.50 \pm 6.85$ & $49.37 \pm 7.04$ & $0.62^{*}$ \\
\hline ASA grade (I/II) & $25 / 5$ & $23 / 7$ & - \\
\hline Duration of surgery (min) (mean \pm SD) & $1.47 \pm 0.80$ & $1.53 \pm 0.80$ & $0.77^{*}$ \\
\hline
\end{tabular}

$*(\mathrm{p}>0.05)$, ASA- American Society of Anaesthesiologists, O-Ondansetron, P-Palonosetron.

Table 2: Incidence of PONV

\begin{tabular}{|c|c|c|c|c|c|c|}
\hline \multirow{2}{*}{ Event } & \multirow{2}{*}{ Time period (hours) } & \multicolumn{2}{|l|}{ Group 0} & \multicolumn{2}{|l|}{ Group P } & \multirow{2}{*}{ P-value } \\
\hline & & No. of patients. & $\%$ & No. of patients. & $\%$ & \\
\hline \multirow{3}{*}{ Nausea } & $0-2$ & 4 & 13.3 & 0 & - & $>0.05$ \\
\hline & $2-24$ & 0 & - & 0 & - & - \\
\hline & $0-24$ & 4 & - & 0 & - & - \\
\hline \multirow{3}{*}{ Vomiting } & $0-2$ & 6 & 20 & 3 & 10 & $>0.5$ \\
\hline & $2-24$ & 3 & 10 & 2 & 6.6 & $>0.5$ \\
\hline & $0-24$ & 9 & - & 5 & & $>0.5$ \\
\hline Nausea and vomiting & $0-24$ & 12 & 40 & 5 & 17 & $>0.5$ \\
\hline
\end{tabular}

Statistically insignificant difference was observed in the incidence of nausea and vomiting between both the groups. ( $p>0.05$ )

Table 3: Severity of PONV.

\begin{tabular}{|c|c|c|c|c|c|c|}
\hline \multirow[b]{2}{*}{ Event } & \multirow[b]{2}{*}{ VAS score (0-10) } & \multicolumn{2}{|l|}{ Group 0} & \multicolumn{2}{|l|}{ Group P } & \multirow[b]{2}{*}{ P-value } \\
\hline & & $\begin{array}{l}\text { Early } \\
\text { (0-2 hours) }\end{array}$ & $\begin{array}{l}\text { Delayed } \\
\text { (2-24 hours) }\end{array}$ & $\begin{array}{l}\text { Early } \\
\text { (0-2 hours) }\end{array}$ & $\begin{array}{l}\text { Delayed } \\
\text { (2-24 hours) }\end{array}$ & \\
\hline \multirow{3}{*}{ Nausea } & Mild & 3 & 0 & 0 & 0 & $>0.05^{*}$ \\
\hline & Moderate & 1 & 0 & 0 & 0 & $>0.05^{*}$ \\
\hline & Severe & 0 & 0 & 0 & 0 & - \\
\hline \multirow{3}{*}{ Vomiting } & Mild & 4 & 2 & 2 & 2 & $>0.05^{*}$ \\
\hline & Moderate & 2 & 1 & 1 & 0 & $>0.05^{*}$ \\
\hline & Severe & 0 & 0 & 0 & 0 & - \\
\hline
\end{tabular}

No significant statistical difference $(\mathrm{p}>0.05)^{*}$, VAS - Visual analogue Scale, O-Ondansetron, P-Palonosetron 
Table 4: Response to the study drugs and need of rescue antiemetic.

\begin{tabular}{|c|c|c|c|c|c|}
\hline \multirow{2}{*}{ Observation } & \multicolumn{2}{|l|}{ Group 0} & \multicolumn{2}{|l|}{ Group P } & \multirow{2}{*}{ P value } \\
\hline & No. of pts. & $\%$ & No. of pts. & $\%$ & \\
\hline Complete response & 18 & 60 & 25 & 83 & $>0.5^{*}$ \\
\hline Incomplete response & 12 & 40 & 5 & 17 & $>0.5^{*}$ \\
\hline RAE given & 9 & 30 & 5 & 17 & $>0.5^{*}$ \\
\hline RAE not given & 21 & 70 & 25 & 83 & $>0.5^{*}$ \\
\hline
\end{tabular}

*Statistically insignificant ( $\mathrm{p}>0.5$ ). O-Ondansetron, P-Palonosetron, RAE-Rescue antiemetic.

\section{DISCUSSION}

The aetiology of PONV is multifactorial; while some causes are well-defined others still continue to be the object of debate. ${ }^{12}$ Even if propofol is substituted for volatile anaesthetics the PONV risk is reduced by only about one fifth, indicating that there are even other more important causes for PONV following general anaesthesia. ${ }^{14}$ Despite the advances in antiemetic therapy in the last few decades, the incidence of PONV after anaesthesia is still found to be relatively high.

All 5- $\mathrm{HT}_{3}$ antagonists have long duration of action with a favourable drug profile. Due to its low cost, ondansetron has been widely used all over the world for PONV prophylaxis. Palonosetron, the latest drug from the same class, has a prolonged duration of action because of its far higher receptor affinity and much longer half-life. ${ }^{15}$ The study by Honkavaara concludes that the use of $8 \mathrm{mg}$ ondansetron was not superior to $4 \mathrm{mg}$ ondansetron in decreasing PONV and the need for rescue antiemetic when given prophylactically in patients who underwent surgery under general anaesthesia. ${ }^{16}$ Though the FDA approved dose of palonosetron in the prophylaxis of PONV is $0.075 \mathrm{mg}$, in our study we decided to choose $0.05 \mathrm{mg}$ as optimal dose for palonosetron in our setup of population. ${ }^{17}$ Hence our present study was carried out to compare the efficacy and safety of the novel, long acting $0.05 \mathrm{mg}$ palonosetron with the already established $4 \mathrm{mg}$ ondansetron in preventing PONV when administered 5 minutes before induction in patients undergoing surgery under general anaesthesia.

The demographic profile and mean duration of surgeries were comparable with no statistical difference between two groups ( $p>0.05$ ), hence we could evenly compare the results observed (Table 1). In both the groups, types of surgeries done were almost comparable (Figure 1). Patients who had events of either nausea or vomiting were 12 in group $\mathrm{O}$ (ondansetron) of whom 3 had only nausea, 8 only vomiting and 1 patient had both nausea and vomiting while none had nausea and 5 reported vomiting in group $\mathrm{P}$ (palonosetron) (Table 2). Nausea was observed in the postoperative period in the group $\mathrm{O}$ only, whereas vomiting was seen in both the groups.

In our study, nausea was observed only in the early (0-2 hours) postoperative period but vomiting episodes occurred in both early (0-2 hours) and delayed
(2-24 hours) postoperative periods (Table 2). The probable cause of early postoperative vomiting could be the use of volatile general anaesthetics. ${ }^{18} \mathrm{~A}$ patient in group $\mathrm{P}$ as shown in Table 3 , with 2.5 hours duration of surgery, had early vomiting (VAS score 4 (moderate)). In the same group, 2 other patients had early vomiting (VAS score 3 (mild)) in whom the duration of surgery was 2.53.5 hours, and 2 more patients had delayed vomiting (VAS score 2 (mild)). Vomiting in these patients could be due to longer surgical procedures under volatile general anaesthetics and nitrous oxide leading to prolonged exposure to them. ${ }^{19-21}$

In group $\mathrm{O}$ (Table 3), 4 patients reported nausea in the early (0-2 hours) period (3 with VAS score 2 (mild) and 1 patient with VAS score 5 (moderate)) who also had early vomiting with VAS 5 (moderate). In this group, totally 9 patients had vomiting. Of them, 6 patients had early vomiting (4 with VAS 2-3 (mild) and 2 with VAS 5 (moderate)) and the remaining 3 had delayed (2-24 hours) vomiting ( 2 with VAS 3 (mild) and 1 with VAS 5 (moderate)). Patient who was given more dose of intraoperative fentanyl $(150 \mu \mathrm{g})$ than others with 3.25 hours duration of surgery had both nausea and vomiting postoperatively. This is in support with other studies which state higher opioid dosage and increased duration of surgery ( $>3$ hours) as the probable risk factors for PONV. $19,20,22$

In group $\mathrm{O}$ (Table 3), 2 patients (1 patient underwent ORIF for \# Mandible and the other thyroidectomy), had vomiting in the early postoperative period with VAS score 5 (moderate). This indicates that the type of surgery also influences the risk of PONV. ${ }^{23}$ The rescue antiemetic (ondansetron $4 \mathrm{mg}$ IV + dexamethasone $5 \mathrm{mg} \mathrm{IV}$ ), was given to $9(30 \%)$ patients in group $\mathrm{O}$ whereas to 5 (16.6\%) patients in group P (Table 4). But no significant statistical difference was observed between both the groups $(\mathrm{p}>0.5)$.

In both the groups patients reported mild and transient adverse events (Figure 2). Total number of adverse events in group $\mathrm{P}$ was $7(23 \%)$ (Headache in $3(10 \%)$ and dizziness in $4(13 \%)$ patients) and $6(20 \%)$ (Headache in 4 (13\%) and dizziness in $2(7 \%)$ patients) in group $\mathrm{O}$. The main side effects of $5-\mathrm{HT}_{3}$ antagonists in the dosages used for PONV were headache and dizziness. ${ }^{3}$ There was no significant statistical difference between both the groups regarding safety profile of study drugs $(\mathrm{p}>0.05)$. 
The present study revealed both ondansetron $4 \mathrm{mg}$ and palonosetron $0.05 \mathrm{mg}$ had similar efficacy and safety which is different from other studies where in palonosetron $0.075 \mathrm{mg}$ was superior to ondansetron $8 \mathrm{mg}$ and ondansetron 4 mg. ${ }^{9,24}$ The effectiveness of ondansetron is comparable with palonosetron could be due to active metabolites of ondansetron (7-hydroxy or 8hydroxyondansetron) contributing to prolonged action of the drug. ${ }^{25}$ Literature search has shown very few studies comparing ondansetron $4 \mathrm{mg}$ and palonosetron $0.05 \mathrm{mg}$ in PONV prophylaxis.

\section{CONCLUSION}

The current study concludes that efficacy of ondansetron $4 \mathrm{mg}$ and palonosetron $0.05 \mathrm{mg}$ in post-operative nausea and vomiting was almost comparable. Since both drugs are serotonin antagonists with almost similar pharmacokinetic and dynamic behaviour the safety profile was also similar in both treatment groups.

Funding: No funding sources

Conflict of interest: None declared

Ethical approval: The study was approved by the Institutional Ethics Committee

\section{REFERENCES}

1. Gan TJ. Risk factors for postoperative nausea and vomiting. Anesth Analg. 2006;102:1884-98.

2. Cohen MM, Duncan PG, DeBoer DP, Tweed WA. The postoperative interview: assessing risk factors for nausea and vomiting. Anesth Analg. 1994;78:716.

3. Kovac AL. Prevention and treatment of postoperative nausea and vomiting. Drugs. 2000;59:213-43.

4. Raphael JM, Norton AC. Antiemetic efficacy of prophylactic ondansetron in laparoscopic surgery. $\mathrm{Br}$ J Anaesth. 1993;71:845-8.

5. Rojas C, Stathis M, Thomas AG, Massuda EB, Alt J, Zhang $\mathbf{J}$ et al. Palonosetron exhibits unique molecular interactions with the $5-\mathrm{HT}_{3}$ receptor. Anesth Analg. 2008;107:469-78.

6. Candiotti KA, Kovac AL, Melson TI, Clerici G, Joo Gan T. A randomized, double-blind study to evaluate the efficacy and safety of three different doses of palonosetron versus placebo for preventing postoperative nausea and vomiting. Anesth Analg. 2008;107:445-51.

7. Rojas C, Stathis M, Thomas AG, Massuda EB, Alt J, Zhang $\mathbf{J}$ et al. Palonosetron exhibits unique molecular interactions with the $5-\mathrm{HT}_{3}$ receptor. Anesth Analg. 2008;107:469-78.

8. Sukhminderjit SB, Sukhwinder KB, Jasbir K, Veenita S, Amarjit S, Anita S, et al. Palonosetron: a novel approach to control postoperative nausea and vomiting in day care surgery. Saudi J Anaesth. 2011;5:19-24.
9. Moon YE, Joo J, Kim JE, Lee Y. Anti-emetic effect of ondansetron and palonosetron in thyroidectomy: a prospective, randomized, doubleblind study. Br J Anaesth. 2012;108:417-22.

10. Schulman ST, Rocket CB, Canada AT, Glass PS. Long term propofol infusion for refractory postoperative nausea. Anesth Analg. 1995;80:636-7.

11. Wang PK, Tsay PJ, Huang CC, Lai HY, Lin PC, Huang SJ, Lee Y. Comparison of dexamethasone with ondansetron or haloperidol for prevention of patient-controlled analgesia-related postoperative nausea and vomiting: a randomized clinical trial. World J Surg. 2012;36(4):775-81.

12. Tramer MR, Reynolds DJ, Moore RA, McQuay HJ. Efficacy, dose-response and safety of ondansetron in prevention of postoperative nausea and vomiting: a quantitative systematic review of randomized placebo-controlled trials. Anesthesiology. 1997;87(6):1277-89.

13. MGI Pharma 2008. ALOXI (Palonosetron $\mathrm{HCl}$ ) prescribing information. Available at URL:http://www.aloxi.com/common/downloads/pi.p df. Accessed on 3 August 2011.

14. Apfel CC, Stoecklein K, Lipfert P. PONV: a problem of inhalational anaesthesia? Best Pract Res Clin Anaesthesiol. 2005;19(3):485-500.

15. Muchatuta NA, Paech MJ. Management of postoperative nausea and vomiting: focus on palonosetron. Ther Clin Risk Manag. 2009;5:21-34.

16. Honkavaara P. Effect of ondansetron on nausea and vomiting after middle ear surgery during general anaesthesia. Br J Anaesth. 1996;76(2):316-8.

17. Kovac AL, Eberhart L, Kotarski J, Clerici G, Apfel C. A randomized, double-blind study to evaluate the efficacy and safety of three different doses of palonosetron versus placebo in preventing postoperative nausea and vomiting over a 72-hour period. Anesth Analg. 2008;107:439-44.

18. Apfel CC, Kranke P, Katz MH, Goepfert C, Papenfuss T, Rauch S, et al. Volatile anaesthetics may be the main cause of early but not delayed postoperative vomiting: a randomized controlled trial of factorial design. $\mathrm{Br} \mathrm{J}$ Anaesth. 2002;88(5):659-68.

19. Stadler M, Bardiau F, Seidel L, Albert A, Boogaerts JG. Difference in risk factors for postoperative nausea and vomiting. Anesthesiology. 2003;98(1):46-52.

20. Sinclair DR, Chung F, Mezei G. Can postoperative nausea and vomiting be predicted? Anesthesiology. 1999;91:109-118.

21. Tramer M, Moore A, Mcquay H. Omitting nitrous oxide in general anaesthesia: meta-analysis of intraoperative awareness and postoperative emesis in randomized controlled trials. $\mathrm{Br} \mathrm{J}$ Anaesth. 1996;76(2):186-93.

22. Roberts GW, Bekker TB, Carlsen HH, Moffatt CH, Slattery PJ, McClure AF. Postoperative nausea and vomiting are strongly influenced by postoperative 
opioid use in a dose-related manner. Anesth Analg. 2005;101(5):1343-8.

23. Lerman J. Surgical and patient factors involved in postoperative nausea and vomiting. Br J Anaesth. 1992;69(1):24-32.

24. Nupur C, Shiv KR. Comparison between efficacy of palonosetron and ondansetron in postoperative nausea and vomiting in middle ear surgery: a randomized double blind study. Int J Pharm Bio Sci. 2013;4(4):67-74.

25. Pritchard JF. Ondansetron metabolism and pharmacokinetics. Semin Oncol. 1992;19(4-10):915 .

Cite this article as: Prakash GB, Rao KU, Subash KR, Reddy KVC, Prasad KJ, Devi BV. Ondansetron versus palonosetron: a comparative study on efficacy and safety in prevention of postoperative nausea and vomiting. Int $\mathrm{J}$ Basic Clin Pharmacol 2016;5:1269-74. 